\title{
"Mestizo cattle is like us people": reflections on cattle, family and coloniality
}

\author{
Leonardo Vilaça Dupin' \\ ' Universidade Estadual de Campinas - UNICAMP, Instituto de Filosofia e Ciências Humanas - IFCH, \\ Programa de Pós-graduação em Ciências Sociais, Campinas/SP, Brasil
}

\begin{abstract}
This article results from ethnographic fieldwork in farms that produce artisanal cheese, in the southwest of Minas Gerais, Brazil. The analysis focuses on the meanings of the practices developed there, especially concerning livestock, which conflict with recommendations of technicians working in the public sector. The latter have tried to manage both human and non-human lives, within a process of development supported by legislation and the insertion of technology, changing the traditional productive practices. This top-down managerial strategy has overshadowed the complex knowledge and the modes of existence empirically observed in these areas. I demonstrate how local practices of mutuality have provided answers that reinvent meanings for life.
\end{abstract}

Keywords: mutuality, cattle, coloniality, peasantry. 


\section{"O gado mestiço é como a gente": reflexões sobre gado, família e colonialidade}

\section{Resumo}

Este artigo é resultado de um trabalho etnográfico realizado em fazendas produtoras de queijos artesanais, no sudoeste de Minas Gerais, Brasil. O foco de análise são os sentidos das práticas ali desenvolvidas, especialmente a pecuária, que têm entrado em conflito com recomendações incididas por técnicos do poder público. Estes têm procurado gestar os modos de vida (humanos e não humanos) dentro de um processo de desenvolvimento que se apoia em legislações e na inserção de tecnologias, obscurecendo os complexos saberes e modos de existência empiricamente observáveis nessas unidades. Procuro demonstrar como práticas locais de mutualidade evidenciam respostas que emergem reinventando sentidos para a vida.

Palavras-chave: mutualidade, gado, colonialidade, campesinato. 


\title{
"Mestizo cattle is like us people": reflections on cattle, family and coloniality
}

\author{
Leonardo Vilaça Dupin
}

\section{Introduction}

"I don't just need to have an idea of the microbiology of my milk. I need to have an idea of everything. The soil, the grass, the cow, the climate, it's a whole thing. This is what makes me see that this specialization is a big idiocy, it's because the blokes (from health inspection) can't see anything of our cheese. [...] But it's not his fault, it's the school that taught him and made him that way. I have to forgive these blokes, but I have to warn them, because they were trained, catechized for that and the fault is of the universities that gave them only that one idea: it's only right if you go through this way, that is the only way you can go through". Luciano Carvalho, farmer, April 2016.

Throughout southwestern Minas Gerais, there is considerable variation in the definition of rural areas where the relation between land, work and family predominates. They tend to be called a "ranch" (sítio), 'homestead" (chácara) or "farm" (fazenda), according to their size, but also to distance from a city and the uses attributed to these places. Since dairy cattle breeding is the rule for most of the rural producers in the Canastra region', "farm" tends to predominate as a preferred designation. The label is generally associated with animal husbandry, although these spaces differ in use and size from the large properties in the region, which are likewise called "farms".

Certain authors have sought to provide more precise definitions. E. Woortman (1983) defines the 'peasant ranch' as a system of diversified spaces, complementary to and articulated with one another, which periodically reorganizes itself in response to the historical process of the expansion of large properties (E. Woortman 1983: 164). According to the author, it is a place that evokes the house, but also the family and a process of descent associated with land use, much as I found among most of the local cheesemakers of the Canastra region.

According to E. Woortman (1983), as places that produce food for internal consumption, they have always been relegated to a marginal position in relation to the so-called noble cultivars - such as coffee and sugar cane - which have been central to Brazilian economic history. In what pertains to the focus of my research, artisanal minas cheese production in Canastra ${ }^{3}$, 'marginal position' is a suitable definition, considering its historical role as food supplier for mining cycles (Dias 2010), and in the present, because of the degree of informality that characterizes the activity. Indeed, although its means of fabrication is in accord with the traditional logic of the producers involved in its fabrication, most of them are in violation of the existing legislation for producing food in Brazil.

\footnotetext{
1 This region is made up of seven municipalities (Piumhi, Bambuí, Tapiraí, Medeiros, São Roque de Minas, Vargem Bonita e Delfinópolis), located around the Serra da Canastra National Park.

2 As E. Woortman (1983) claims, in a study carried out in the Brazilian state of Sergipe, the use of the term "farm" has undergone a historical transformation. Decades ago, it did not refer to large tracts of owned land, as it does today, but rather to the economic activity of livestock husbandry.

3 By this expression, I refer to food produced by traditional, family means in the region, which defines an artisanal mode of production, declared national heritage in 2008. I wrote a doctoral thesis about this food, defended in March of 2019, which discusses conflicts between producers and state agents. I carried out fieldwork in the region between 2014 and 2018.
} 
There are estimated to be currently some 30,000 families producing food in Minas Gerais. Of these, only some 300 abide by legal norms, and are thus formally authorized to produce and sell their products ${ }^{4}$. In Canastra, a landscape of more than 800 families involved in the activity, only 57 families are regulated (which is around $7 \%$ of local producers)s. The vast majority are at the margins of the law, unable to legally place their products within the large distribution networks, since they do not abide by the set standards, which would demand modifications in how the cheese is handled and in the structure of the properties, but also transformation in local ways of life.

Returning to the predominant use of the term "farm" in the region, which stresses the role of cattle in the typology of properties, we encounter a first feature of the importance of these animals for rural producers. As we will see, cattle, which played a decisive role in the colonization of the region, acts as a subject in the construction of social identity and position for the families of the region. Cattle is both the product and a producer of places (farms) and people (farmers), but also an agent of work, affect and memories. This article concerns these animals and their owners.

In an article that describes the specificities of the construction of Brazilian elite cattle, with which I will engage in this article, Leal (2014) claims that cattle husbandry in Brazil is enacted as a "statement of alliances between humans and nonhumans: it is economy and symbol, purity and mixture, accident and design, medium and technology, nature and culture, and therefore an anthropological subject par excellence" (Leal, 2014:15).

I start not from a field of hegemonic power, as Leal did, but from small units of production, with characteristics of a peasantry, in which family work with these animals is predominant. The productive units and their actors - who "seal the pasture", "make the cattle", "create families"- will be described and analysed in their multiple relations, propitiating an understanding of the meanings that compose local ways of life, which are now confronted with exogenous knowledges and standardizations. In the pages which follow, I will discuss these producers, and also their animals.

\section{The farm: seasonalities, mutualities and knowledges}

It is early November. When the rains start to fall in the Matinha Farm ${ }^{6}$, Otusseziano Freitas (Otinho) cannot conceal his joy. Opening a wide smile, he exclaims: "Ohhhhhh St. Peter, better than this only a winterness"' The rain welcomed on that day marks the passage between what is locally conceived as the two seasons of the year: the drought and the green. The first is marked by a dry period which usually starts in May and continue until the end of September. The second is marked by high temperatures and rains, covering the period between October and March.

\footnotetext{
$4 \quad$ It should be pointed out that the main health laws for dairy products in Brazil are currently divided between the federal, state and municipal spheres. The most important laws operating in the state of Minas Gerais are the Regulation for Industrial and Hygiene Inspection of Animal Products (Regulamento da Inspeção Industrial e Sanitária de Produtos de Origem Animal - RIISPOA), a national law of standardization, and the state law no 20.549, from 2012. For both laws, the established requirements associate "quality" with "harmlessness", according to international standards for industrial production which, in general, demand investments in construction (cemented corrals, tiled cheeseries, mechanical milking, etc.), and require that producers undergo training courses and make use of such items as aprons, gloves, hairnets, masks and rubber boots. In short, legislation generates costs and imposes standardizations on the body of producers which are beyond the means and outside of the interests of most of them.

5 Data concerning Canastra come from research carried out in 2014 by the Association of Canastra Cheese Producers (Associação de Produtores de Queijo Canastra - Aprocan), in partnership with the Brazilian Aid for Micro and Small Businesses (Serviço Brasileiro de Apoio as Micro e Pequenas Empresas - Sebrae).

6 The property is situated eight kilometres from the city of São Roque de Minas, MG, straddling the Canastra Hills National Park.

7 "Winterness" (invernada) is a polysemic term in the region. It can indicate a prolonged period of rain over various days. However, it can also designate highland pastures in the rainy seasons or even how the animals get fat during the period. When I asked Otinho about its meaning, he said it meant "rain for many days" or "sealed pasture". Despite their different referents, all of these meanings are associated with managing the animals of the property.
} 
According to Otinho, this year the rains were "delayed" a few weeks and the drought was extended, threatening the food supply of the herd. After asking a few questions, I come to understand what the transition means to him: "it's the time when the pasture gains strength and comes out", when "it is sealed" ${ }^{8}$, but, more than this, the rains kick off his chain of work. "Rain is good. Pastures become green. It's abundance", he replies.

Pastures make up most of the farmland in the region. They tend to stick out in the hilly landscape of Canastra, occupying the horizon, shot through with stone walls that even today demarcate some of the limits between properties. The walls are the most visible legacy of the process of colonization, which began in the second half of the $18^{\text {th }}$ Century, "characterized by the struggles of the bandeirantes 9 against the Indigenous [...] and Maroon communities that occupied the left banks of the São Francisco River, where cattle farms were installed" (Fernandes, 2012: 28). The Portuguese brought the animals to the region as a means to occupy territory, and with these animals came the technology for cheesemaking ${ }^{10}$.

At present, in Matinha Farm - as, indeed, in all of the other properties I visited in the region - pastureland is divided into two portions: "pasture for bachelor cattle" and "pasture for lactating cattle". The former is situated in more distant areas, far from the farmhouse, typically in steeper land. The latter is situated closer to the farmhouse and the corral. It is one of the most closely managed areas, and therefore one of the most compartmentalized.

Two years after observing the experiences of their neighbours and relatives (a common way of exchanging knowledge in the region), Otinho and his wife Eliana adopted the use of stakes and electric barbed wire fencing to divide their pasture for lactating cattle into 31 polygons. Each one of these is covered with a type of grass known as Mombaça (Panicum maximus), of African origin, but improved under laboratory conditions and introduced in Brazil by a public institute for agricultural research in the $1990^{\prime} \mathrm{s}^{11}$. Mombaça is highly resistant to "pests" and to cattle, growing rapidly and densely, supplying a good quantity of food for the herd, allowing cows to gain weight and produce a fatty milk, essential for cheesemaking.

The property also has 'fat grass' (Melinis minutiflora) and signalgrass (Brachiaria decumbens), both also African genera of forage, the latter having likewise been introduced by research institutes, spreading rapidly throughout the Cerrado ${ }^{12}$. Both species adapted well to local soils and climate, easily reproducing under the care of the producers. Today they are known as "tame pasture" "13, "technological grasses" ", or "invasive species" ${ }^{15}$, according to, respectively, producers, technicians, and environmentalists - which indicates that they are a source of conflict.

\footnotetext{
8 The term indicates the regrowth of the pasture, which recovers with the rains from the dry period and cattle trampling.

9 Settlers and fortune hunters hailing from what is now the Brazilian state of São Paulo, who led expeditions to occupy the Brazilian interior.

10 Portuguese territorial occupation of the Canastra after 1750 was a way of expanding the agricultural frontier and ensuring Lusitanian dominion over the territory against Spanish ambitions. The Crown distributed lands, exempted settlers from taxes on agropastoral activities, and carried out campaigns to displace and exterminate Indigenous communities (composed mainly of the Kayapó and Cataguá) and maroons (the maroon communities of Ambrósio and Queimado) who occupied the region. Existing forms of organization were thus substituted by cattle farms, occupied by poor settlers, transformed into a dependent peasantry, and the agropastoral economy expanded throughout the region through these actors, who have historically composed the pattern of small landholdings that are at present spread throughout the region.

11 The grass was released in Brazil by Embrapa Beef Cattle in 1994.

12 Until the 1970s, fat grass was the most common grass in Brazil, before a replacement programme started substituting it for more productive grasses, mainly signalgrass species introduced by the defunct National Department of Research and Experimentation (currently Embrapa). Cattle in Minas Gerais consume mostly this type of grass at present.

13 A domesticated nature, good for human labour and for being eaten by animals.

14 Genetically enhanced in a laboratory.

15 This label is used when individuals of a non-native species arrive in a region through human assistance, and establish a population that comes to have negative effects on the environment.
} 
Grass may, at first, seem to be of little interest to an anthropological study ${ }^{16}$. However, Otinho's views on pastureland are a clue that grass may provide a first step in understanding a series of complex relations between human-and-social ("humanos-e-sociais") beings and nonhuman beings, the latter capable of being socialized (Brandão 1999), involving the land as a space where life and work is organized. This set of relations, based on reciprocity as a value (Woortman, 1988), is encountered in many peasant societies, and, in the present context, has cheesemaking as its guiding thread.

Conceptualizations of these types of relations are varied: Woortman (1988) refers to homo moralis, to characterize this relation in which land as a value is counterposed to a utilitarian conception of its use. Brandão (1999: 17) points to the existence of a peasant ethos which works through values, principles and sensibilities, wherein codes of exchange are vitally and symbolically incorporated to social life, to the imaginary, and to social and cultural codes. Ploeg (2008) refers to co-production, which consists in the constant mutual interaction and transformation between the peasantry and living nature as a way of improving the resource-base of the property, thereby ensuring the autonomy of the agricultural unit.

However, as I see it, the relation in question here goes beyond the economic sphere - and I here include both the Functionalist and Symbolic-ecological approaches known as "good to eat" (Evans-Pritchard, $2013 \mathrm{e}$ Harris, 1978) and the Structural "good to think" approaches (Lévi-Strauss, 1983). I propose to move toward the more contemporary repositioning of "companion", "interdependent" species, "good to live together" (Haraway 2008; Tsing, 2015; Paxson, 2013) ${ }^{17}$, studying relational processes of the co-constitution of social entities of all sorts, which dissolve the frontiers that isolate nature and culture, and which I will here call mutualities (Pina-Cabral e Godoi, 2014: 14) ${ }^{18}$.

In brief, this perspective considers a complex "ecology of beings" that cannot live apart, and which will therefore be described in contact with a wider world within which knowledge and life are deeply enmeshed. It is a matter of conceiving of dynamic means in which species do more than merely meet, since their relation emerges from co-evolutionary histories that involve processes of co-becoming within the complexity of worlds-in-processes, through the tangle of zones of contact and relations of power that can be historicized and described ethnographically. After all, "beyond mere survival, particular forms of life, in all their resounding diversity, emerge from interlinked patterns of living and dying, being and becoming, within a wider world" (Van Dooren; Kirksey; Münster, 2016).

In what pertains to cheesemaking in the region, these relations cut through the creation of pastureland, agropastoral lifecycles, and through the actions of bacteria and yeast in the fermentation of milk and the maturation of cheese, involving, still, inter-relations between numerous other species in their spatial-temporal patterns of organization. Through the mutual and constant interaction and transformation that emerges during food production, we begin to understand the relations of meaning, interests and affects. A network of relationships that, we will see shortly, contrasts with industrial, technoscientific agriculture, but also with hegemonic knowledges and powers, and which therefore are the object of constant tension.

\footnotetext{
16 What I mean by this is that the objects formulated by classic anthropological thought, which permeate the humanism and multiculturalism of the $2 \mathrm{O}^{\text {th }}$ Century, have almost always been framed in anthropocentric terms, registering a qualified life, described and analysed as political, cultural and social experiences, in opposition to an external, objective nature, which would be of little interest to the discipline.

17 The first two authors are part of a field of studies characterized by thorough practices of attentivity to an interspecific mode of being of species that are continually modelled and remodelled. Tsing (2015: 185) speaks of "complex relations of dependency and interdependency"; Harraway (2008) analyses persons and things mutually constituting each other as constituents in intra- and inter-relations. In a study of cheesemaking farms in the USA, Paxson (2013) calls this "cultured nature", resulting from the ability of farmers to work in collaboration with environmental agencies.

18 The sense used here is similar to that described by Pina-Cabral and Godoi (2014), who see mutuality as constitutive of the relations between persons The concept here implies an intersubjective dimension, understood as the very possibility of interaction, whether between humans or nonhumans.
} 
The first choices for Otinho, as for other farmers in the region, are in the pastures. These are the subject of calculations which soon drew my attention, standing out for the regularity with which they emerged as phenomena that involves the management of the whole property ${ }^{19}$. Pastures are involved in a universe of care that includes choice of foraging species, types of management strategy, number of animals to be kept, and, above all, timing. In other words, evaluations centre on the number of cows that the pasture's grass is able to sustain for a set period, without this relation entailing losses in herd productivity, such as reductions in the rutting time of the cows and the quantity of milk produced, as well as avoiding degradation of the forage and the soil.

The period of "rest", when cows are removed from the pasture, allowing it to reach its ideal size for rumination, is what Otinho calls "time to seal the pasture". This is a practice which depends on factors deemed to be natural (such as the seasons), but also on a family workforce (much of the time spent in the properties is dedicated to upkeep of the forage), and, increasingly, on technology developed beyond the farm, such as the selection of grasses, constant fertilization, etc. All of this determines the performance of the herd (and, consequently, the social reproduction of the family), since the amount of milk obtained is directly dependent on the conditions of the pastures.

"With this picket we stopped planting gardens and things got expensive for us. The picket is good, but to implement it in the nick of time, we spent some six thousand, two thousand Reais per hectare, but the true cost is 800 Reais to manage it. It increased 100 litres of milk per day, and allowed the property to sustain another 15 cows. I had 30 cows and the grazing land was all eaten up, there was no pasture, now I keep 45 cows and my pastures are sealed. And when your pasture is sealed it yields more milk, because it also keeps the cows fat, spends less fodder". Otinho, December 2016.

The care that a farmer calls "zeal" veers toward the pastures. It is also in the pastures that we can see how the incorporation of technologies in Matinha has been occurring gradually, according to the calculations of the couple, involving knowledge transmitted down generations and relations of reciprocity (the exchange of experiences with neighbours and relatives, as well as the experiences of former generations). However, such incorporation has also been occurring via government demands that seek to standardize dairy production according to technological patterns, enclosing farmlands with fencing line with a rationalization process that seeks to limit the movement of animals (Andriolli e Pereira, 2016), bringing them closer, within a process of mercantile domestication.

Before the creation of the Parque Nacional da Serra da Canastra (Canastra Hills National Park, PNSC), in the mid-197os ${ }^{20}$, for example, most farmers in the region carried out seasonal transhumance, keeping two areas for feeding the herd: one high up in the tablelands, currently under the control of ICMbio ${ }^{21}$, where we find the predominance of a savannah vegetation composed of a variety of low-lying species, which acted as pasture reserves during the winter months; and another in the ragged valley bottoms, were we find mostly "fat grass", which has been gradually replaced with signalgrass. As one farmer told me: "Everyone had land up there [in the tablelands], those who didn't rented it. (...) After it was expropriated, it was miserable, we had to stay only in the lower areas and had to plough and plant the signalgrass".

\footnotetext{
19 On 'peasant calculations', see Carneiro (2015), who uses the expression to define a sort of knowledge that does not aim for an exact result, but toward subjective contingencies that create relations based on trust.

20 The PNSC was created in 1972, with 200,00o hectares, of which 71,525 were expropriated land (the area known as the Canastra tablelands), coming into the possession of the State. The remaining area is made up of private rural properties, mostly small to mid-sized farms used by peasant families that raise dairy cattle and carry out subsistence cultivation. These families have lived under the risk of expropriation ever since the Park was created, which is a source of great insecurity, having an impact on the dynamic of social reproduction of these families. See Cintrão and Dupin (2018) for a more detailed analysis of the theme.

21 Federal agency presently responsible for the administration of national parks in Brazil.
} 
This is what happened to Otinho's family. During the wettest months, from October to March, his herd would feed in the lowlands, close to the foot of the hills. During the dry season, from May to September, when the lowland pastures were exhausted, the animals were taken to the tablelands, where there was an abundance of native grasses, allowing the planted pastures to recover. Some neighbours had retreats (the so-called 'stone corrals') to spend all of the rainy season with the herd. Others, like his father, would "bachelor cattle" and "lactating cattle" in the tablelands. What was crucial was that a few days before the animals went uphill the area was burned, and farmers took turn seeing to that.

The use of fire by farmers is an ancient practice, and though it may appear rudimentary (which is how the ICMBio employees see it), it has sophisticated elements, requiring a deep understanding of the environment, as evidenced in the narrative of the regional population. It is a science of the concrete (Lévi-Strauss, 1976), practiced seasonally, with native fields classified in three ways throughout the year: "field" (when the grass is green), "macega" (when the grass is dry) and "burnt" (when the grass remerges, after the fire).

To burn the "field", local farmers take different factors into account, such as the time of year (after the first rains, while the soil is still moist), the gradient of the terrain (always from the top down, since "no one can stop fire going uphill and water going downhill"), wind direction (fire is set against the winds, and counter-fires are set with the winds so that they may find the fire in the other direction and put it out). Fallows and forest on the riverbanks are preserved by fire belts made during the day, cutting undergrowth at the edges, setting fire and putting it out, little by little, in order to widen the belts.

When it was allowed, fire was usually set at night, when it was cooler and the winds were less intense. It was also set in turns, with a biennial break: each farmland was divided into two and half of its area was burnt every year. Burned areas were alternated between contiguous farmlands. The technical process thus required collective planning, with work parties organized to help make the fire belts and to control the fire, the farmers of the areas being burned taking turns. Since the areas immediately beside those being burned had been burnt the year before, fire management was facilitated and, according to local farmers, rarely got out of control (Cintrão and Dupin, 2018) ${ }^{22}$. As one farmer said: “They say you can't set fire, but the counter-fire is a system in which you put out fire with fire. (...) People here know how to control fire because we're not arsonists, we set controlled fires".

According to local inhabitants, the practice was carried out following traditional knowledge and was adpated to the ecological characteristics of the region, respecting the reproduction of endemic species (emus, maned wolves, armadillos, deer, etc.). Native species were considered to be semi-domesticated by older inhabitants, since they lived in close proximity to local farms and "learned" the rotating system of the so-called "mild fire" (controlled), adapting to this management practice. According to farmers, emus, for instance, made their nests near water sources, and "when the fire came, she jumped in the water and wet the nest, protecting the eggs". The fire rotation was also seen to preserve the roots of the fodder by not burning them, since some two weeks after the fire, the "burnt" becomes a "field" and is again ready to receive fully-grown cattle.

Economically, the practice does not need an extensive workforce ${ }^{23}$, has low costs and is very efficient, ensuring food for cattle and avoiding competition over arable land and the reduction of milk produced by the herd (Barbosa, 2007). Local people also claim that it avoids uncontrolled fires from reaching the areas where people live, since the belts prevent flames from moving into these areas, keeping them safe and maintaining areas of preservation, and, thereby, a water supply for cattle and the stock of timber for building tools, fences, corrals, houses and cheeseries.

\footnotetext{
22 I also heard reports in the influence of the lunar cycle in this process, adding another element that ensures that the fire is "thinner" with a "more beautiful rebirth" of grass.

23 Farmers see this is one of the main problems that they currently face, since their children emigrate and they find it hard to hire employees in the region.
} 
These management practices hark back to colonial times. They apparently result from a European practice that incorporated Amerindian techniques, undergoing small adaptations as a result of the biogeographical characteristics of the region. In a study of the Canastra region, Barbosa (2007) identifies the division and management of pastureland through the use of fire, and the system of allowing gardens to lie fallow, as legacies of Amerindian agricultural practices, which proved better adapted to the tropical environment than their European counterparts. "Within the range of choices put to the settlers, they selected those that they knew would work, watching Indigenous people or learning from enslaved Amerindians, often after trying and abandoning those techniques brought over from the metropolis for being inadequate" (Barbosa, 2007: 183).

The reproduction of agricultural techniques with these characteristics was studied by authors such as Cândido (1982) in the Bofete region of São Paulo, Brandão (1981) in Mossâmedes, Goiás, Woortman (1983) and Moraes (2009) in the São Francisco Valley in Piauí. Similar swidden techniques also seem to be found in Africa. In Evans-Pritchard's (2013) classic study of the Nuer, for example, we learn that these Nilotic people lived from cattle pastoralism in the Sudan, migrating according to the seasons, and using fire in the savannas for regrowing grasses. The author sees burning, which occurred in the shift from the rainy to the dry seasons, as vital to the survival of cattle, and hence of the Nuer population ${ }^{24}$.

Otinho and Eliane are currently two of the many farmers that live in the vicinity of the Park who claim that the creation of the conservation unit increased the number of fires in the region. Local people often have to protect their land from uncontrolled fires which, they claim, starts in the expropriated tablelands and reaches their properties:

"The fire comes from the Park at the wrong time, and then it's worthless. Because fires need to be set at the right time, between the end of September and the start of October. After a good rain, you burn the field. Now the fire arrives in August, in that wild soil, and then it kills everything. Then it doesn't rain, and the burning doesn't stop, you know? And then instead of being a good thing, it ruins everything. It kills the field, doesn't make pastures. Fire at the wrong time is just awful. (...) You need to burn the field every two years. Then what happens is that the Ibama won't allow you to set fire. Then it's five years without burning, and it gets this high. Then the fire comes, burns, and kills it all, it gets really weak. Now, if you burn every two years it strengthens it, you understand? It's like when we cut our hair, it gets stronger". Otinho in October of 2015.

The expropriated area was thus strategic to the local socio-productive system, a part of the economic and moral calculation of Otinho's family, but also of other families in the region. However, with the establishment of the PNSC and technological innovations, considered more modern and efficient forms of management, serious restrictions to the use of this agricultural practice in the region were introduced, de-structuring (at least partially) the existing system. Thus, when Otinho's father was forced to "sell" part of the lands to the State, he and other families in the region were forced to adapt the system that operated in Canastra, ceasing to set fires and to take the cattle to the tablelands.

Transhumance was gradually replaced by a system of rotating pasturage of technological grasses, use of silage - at present used during winter - combined with the incorporation of livestock feed in the diet of the animals. The same happened in the tableland areas expropriated with the creation of the Park, where the social

24 Eric Wolf (1976) claims that burning techniques are similar to the paleotechnical eco-types of the first agricultural revolution. At present, many biologists argue that the best way of preventing uncontrolled fires and preserving the biodiversity of the Cerrado, is, precisely, the controlled use of fire. They argue that the controlled use of fire reduces the amount of accumulated organic matter which acts as fuel during fires caused by lightnings or agricultural activities. Furthermore, it speeds up the process of recycling nutrients, allowing them to be used up faster by low-growing species, ending the vegetal dormancy of the seeds and creating fissures that favour the penetration of water and stimulate germination. See: http://agencia.fapesp.br/especialista_defende_manejo_ de_fogo_no_cerrado/17303/ 
uses of these territories for agropastoral activities, hunting, fishing and food gathering, as well as for events of sociability (festive and religious rites), were suppressed within the administrative mechanism of the Park, which favours scientific research and tourism.

The standardizations of government power brought with them new meanings and ways of relating to space, causing sociocultural and technological transformations. However, these new standards were incorporated into a pre-existing cultural logic. As Brandão (1999: 57) states, they are only integrated as maps and modes of social dispositions of relations insofar as peasant culture incorporates and acts upon them, while operating the cognitive systems of a logic of nature and its relations to human society, and an ethical semiology of sensibilities and dispositions, involved in such acts of reciprocity. Fires thus never ceased to be set, which is a constant source of conflict with government agencies.

In the last decades, farmers have been criminalized by administrative agencies for perpetuating their traditional way of life, whether by the use of fire, or for other management techniques, including those stemming from restrictions imposed on the use of the Areas of Permanent Preservation, close to creeks, which are responsible for the decrease in the flatter and more fertile agricultural areas of the property, and also those related to food production that defy sanitary and productive standards (vaccination practices, ways of milking and fabrication). All of these standardizations, violations of which usually result in fines, but also in seizures and pressure to abandon outlawed activities, have placed farmers in a condition of illegality, and has legitimized, by means of resolutions, the incorporation of foreign technologies into their productive systems.

\section{“Making cattle": reflections on man, bulls and customs}

Otinho and Eliane currently own 49 lactating cows, part of a herd composed of cattle that they call "mestizo". It results from the acquisition of animals of different races (cattle and zebus) 25 and varieties of cross-breeding. It is known as "mestizo" because the procreation processes of previous generations included no formal monitoring ${ }^{26}$, maternal and paternal lines not being expressed in pedigrees ${ }^{27}$. In their herd there is no uniformization of the animals, which vary in colour, build and traits, though they identify some cows as Caracu, others as "facing" toward Nelore, Guernsey, Holstein Friesian, Gyr Cattle, and some which are "armadillo-snake" 28 .

It is Saturday morning and we are in the corral. Otinho speaks of the difficulties he has been facing and the progress he has been enjoying for twenty years, since he married Eliane and acquired the property to carry out what he called "making the cattle". This is a common expression in the region which, briefly, refers to the gradual quantitative and qualitative accumulation of a herd for daily care, which will economically guarantee the farm's expenditures through the production of milk and calves, ensuring the reproduction the way of life of a "farmer".

\footnotetext{
25 Bovine races can be separated into two main groups, cattle (Bos Taurus) and Zebus (Bos indicus). Although both originate from a common ancestral stock, they have evolved in very different environments, and therefore today diverge significantly in many aspects. As a rule, cattle (Angus, Simmental, Limousin and Holstein-Frisia) are European animals that evolved in temperate climates, while zebus (Gyr, Nelore, Brahman, Guzerá) are Indian and have evolved in a tropical climate.

26 Despite the fact that breeders control the breeding of the herd, knowing how to describe the ancestors and progeny of each animal, as I will demonstrate shortly.

27 The pedigree (through inbreeding) is a mechanism that attests to purity and distinction through the publication of the genealogy of animals considered to be "noble". It emerged in the $18^{\text {th }}$ Century from the experiments of the Englishman Robert Bakewell, and later became a consolidated industry in various parts of the world. It is currently being used in "racializing" domesticated animals, such as cattle, horses and dogs.

28 The term indicates an animal of indeterminate race. I will return to it shortly.
} 
In the region, one "makes cattle" by buying, selling and exchanging, but also through inter breeding that can confer some sort of adaptive advantage to the animals, such as physical resistance to the vagaries of local weather and acclimatization to the steep slopes, immunity to worms and ticks, and, particularly, to ensure that every animal is able to produce more milk without increasing the area of its pastureland these measures have been successful in Matinha over the last years (from 5 to 6.5 litres on average per animal). The incorporation of basic zootechnical notions of verification and the fixation of attributes has led people to speak of the blood of animals in terms of fractions: half-blood; 7/8 blood; 15/16 blood, etc... According to Otinho, his aim is to "verify the blood", that is, to "fix" genetic constitutions in his animals, until they take on the characteristics of half-blood cattle, the Girolando (Gyr + Holstein) ${ }^{29}$ cattle, which is simply managed and produces a greater quantity of milk without losing the "rustic" aspects that throughout the region are associated with resilience.

"Making the cattle" tends to be a long and complex procedure of biological construction, but it is also seen to result from work. Thus daily engagements with the herd are fundamental, as are relations with funding agencies, neighbours and relatives, with whom one exchanges, and the search for new clients to buy local products, such as calves and cheese. It often also involves relations between bosses and clients, the latter receiving a percentage of the offspring. With all this care, it is often heard that farmers "live for cattle". Otinho likes to say that "we work together, we care for the herd and they give us a return". Understanding this "bovine" idiom, to borrow Evans-Pritchard's (2013) expression, is the next step we must take to understand the rationality between farmers in the region and to think of relations of co-constitution.

In a thesis on the invention of Brazilian elite cattle, Leal (2014) shows how, during the last century, cattle breeders made themselves into an elite along with their cattle, which they bred according to an original way of establishing pedigrees ${ }^{30}$. They thereby consolidated themselves as a politically and economically influential elite in the country. Leal refers to the work of anthropologists who study kinship, reproductive technologies and human-animal relations, such as Mary Bouquet (1993), Marilyn Strathern (1999) and Rebecca Cassidy (2002), among others, who investigate themes such as purity, heredity and human-animal kinship.

Cassidy (2002), for instance, studies the "invention" of pedigrees among pure-bred racehorses in England. She argues that the market for these horses informs us much about local aristocracy, since pedigrees "carry" the history of the "bloodstocks" industry, based on patriarchal, hereditary and aristocratic criteria. As the author shows, it is no coincidence that these "pure-blood" horses are owned by families which are also "pure blood", as it were. These elite animals, with a high market value, have become repositories not only of genetic material, but also of a racial ideal. Pedigrees do not only make evident mechanisms of inheritance, of belonging to a group, a race or a family; they also produce individual distinctions, whether between men or between animals, generating mutual prestige (Cassidy in Leal 2014).

As Leal (2014: 18) shows, the elite bovine market (of "blood stocks") in Brazil is also constructed via a rhetoric of the "elite", but with specificities related to so-called tropical zootechnique, such as the "control of the animals' blood flow" and the regular publication of genealogies. As she shows, Brazilian breeders invented their own way of selecting and "racializing" cattle, which involves socio-economic, but also aesthetic, criteria. Thus if these animals are not the property of a "pure-blood aristocracy" in Brazil ${ }^{13}$, they are nonetheless undoubtedly the

29 The Girolando is the interbreeding of the zebu (mainly Gyr) with European cattle (Hosletin). It was recognized by the Ministry of Agriculture in 1968. Some authors have observed that, in the past, the Canastra was the cradle of the Caracu breed, and gradually mestizo animals, stemming from zebu races which produced little milk, came to predominate. Even later, specialized races were introduced, resulting from interbreeding between zebus, mainly Gyr, and European races (Holstein), until the Girolando was produced. It is currently one of the most used races in the region (Meneses, 2006).

30 Leal studies the construction of Zebu cattle, through fieldwork in Uberaba, Minas Gerais, about $230 \mathrm{~km}$ from the Canastra region. The Uberaba area underwent a colonization process in which it maintained strong commercial ties with the Canastra (Lourenço 2005). Uberaba became one of the main towns of the Empire, and, in the $20^{\text {th }}$ Century, a modernization pole in the interiorization of the country.

31 Unlike the United Kingdom, Brazilian titles of nobility were not inherited by "blood" and transmitted through a lineage, but bought from the Imperial government. 
property of a wealthy upper class that made itself - and still makes itself - through their cattle and an idiom of kinship. As the author observes, for generations Brazilian breeding families have selected and commercialized bovine families. They are not the owners of these specimens, but detain the necessary knowledge to select and commercialize them, which is fundamental to constructing a market for elite cattle ${ }^{32}$.

According to Leal, the genealogies of these heads of cattle are more than registers of the transmission of substances and attributes. They result from authorship. By selecting specimens, breeders elaborate ideal matings, since they have a deep knowledge of the ascendency of the cattle. Basing themselves in ideas of "blood", heredity and genetics, they envisage the generation of superior progeny thus creating elite specimens. A successful bovine genealogy produces heads of cattle as much as it produces elite breeders (Leal, 2014: 20).

Leal (2014) is able to establish a correlation between men and elite cattle, which are dear to family markets like this branch of livestock breeding, where the kinship idiom (either through "blood", heredity, genetics, genealogies, families) matters to "elite animals" and to breeders, making itself present in mutual evaluations. In the hands of the elite, these animals become objects of purity and distinction. The author concludes that the invention of the Brazilian formula for selecting these animals has a political, rather than simply zootechnical, meaning. Through "racializing" animals, occupying territories, and using biotechnology, elite animal husbandry links farmers and the State to a common project of family, nation and race.

Concurrently, it is telling that, at the opposite end of the "pure-blood" national cattle, far from the formal registries, in the midst of a "mini-landholding structure, where properties are generally smaller than 100 Hectares, where cattle breeding occurs in a traditional manner, lacking modern technologies" (IBDF, 1981: 29) ${ }^{33}$, what predominates in genetic terms is cattle categorized as "mestizo", of undefined bloods, diversified, resulting from inter-breeding different races. Breeding these cattle are fourth- or fifth-generation peasant families descended from a process of colonization that originates in wars against Indigenous and maroon societies, as well as mechanisms for fixing a workforce of free and poor whites of Iberian descent, such as those groups who led the occupation of the Canastra region and its agropastoral development (Lourenç0, 2005). As I often heard in the region, 'mestizo cattle are like us, they've got everything".

Otinho's definition of an animal as being an "armadillo-snake" - which synthesizes this process of intermixing - reveals how the race of the animals implies a socio-territorial segment. At the heart of it is a "blood" that ties men and cattle, to which certain qualities are attributed and which come to metaphorically represent a situational and relational ethnic boundary (Barth 200o), only explicitly activated in specific contexts that set the farmers of the region apart from a distant elite that possesses "pure blood":

"The armadillo-snake is a head of cattle without a definite race. It has mestizo, Caracu, Gyr, Guernsey, everything in a single blood. So it's not a race, it's an armadillo-snake. It's just like the Brazilians, because there's Indian with Black with Italian with I don't know what. Here in our region you still have the odd farmer who has a pure Holstein, any other race will be pretty hard to find. The land here is all small (...) In the Calçiolândia Farm ${ }^{34}$ they make Gyr. There they've got the genetics neatly tied up. They're the only ones with that good race. You see? Fifty years they've been making the cattle. Now there's twenty years I'm making it, but first I didn't have the cattle, I was buying little cattle to make, now I want to make my cattle from a Gyr (bull). I'll put the Gyr and make the cattle.

\footnotetext{
32 See Preiswerk (1995) and Pellegrini and Marie-Dominique (2014) for other examples of how methods of management stamp emblematic identities on cattle, and pedigree books tend to promote the image of the race as a morphologically stable set of animals. These authors show how the idea of "pure race" is defined as resulting from choices effected by the members of genealogical books, and devices which mask a meticulous and deliberate process of selecting, construing this group of selected and adapted animals as resulting from a natural adaptation.

33 These words are taken from the firs Management Plan of the PNSC, written in 1981.

34 The Calciolândia Farm is located in the Municipality of Arcos, 115 km from São Roque de Minas. It is one of the largest breeders of dairy Gyr in the country, known for breeding, selecting and improving cattle. The farm belongs to one of the wealthiest families in Brazil, which has sought knowledge from the agrarian sciences in other countries since the start of the last century, acquiring a number of imported animals.
} 
But it won't be special cattle, there'll be armadillo-snake in there, because we'll come out with some Girolandos, some only backed up, because my cows aren't pure" (Otinho, December 2016).

The speech is emblematic; it resonates with what Leal (2014) has written on how cattle breeding constitutes a monument (Foucault 1972) ${ }^{35}$, which can, accordingly, be dismantled and investigated, thereby affording us new understandings, since it converges diverse concepts, themes and theories that relate men and cattle in the Nation State's modernizing project. It is thus necessary to investigate how these animals affect and are affected by people beyond the productive circles and places (the comparative denomination not being a coincidence here), mirroring political relations and identity politics more widely.

As was made evident during fieldwork, Otinho and most of his neighbours are not part of an economic or political elite. They are peasants, who store their savings in cattle. Since, historically, throughout the region, work in pastures and gardens was often paid with animals and ownership over the lands one worked on, these families composed a social mosaic that took form over many decades. At the margins of the dominant economic system, a network of kinship and knowledge was constituted, involving people and cattle, and which today is linked to cheesemaking farms in which neighbourly ties are fundamental elements in socio-economic organization.

However, since even today knowledge of breeding in the region is not exactly identical to that "invented" by tropical zootechnique, developed in research labs and published in scientific journals, the social representation of local herds - as conformed by public agencies of research and inspection ${ }^{36}$ and their technicians - point to the demerit not only of the animals, but also of their owners, subsumed under a (symmetrical) shared ethos as "rudimentary", "backward", who should not even exist given their "technical inefficiency" and "precarious relations with the market". These technicians and administrators, sent to rectify local "deficiencies" (Ribeiro 2008) ${ }^{37}$, with the power to determine standards (according to scientific and legal points of view) and, at the same time, to ensure that they are obeyed (as public morality), are guided by value judgements that obscure - or even make illegal - the complex knowledges and empirically visible ways in which these units function.

It should be stressed, as Leal (2014) reminds us, that heredity does not act alone in configuring the "purity" of elite specimens, since management is also an unavoidable condition of selection. The author argues that an elite specimen is also the result of a confluence of care, alongside factors such as pedigree and exposure. For cattle to be considered elite, it is not enough to embody exemplary racial patterns or to be a Pure in Origin specimen; it must also embody the efforts of the breeder who elaborated it (Leal 2014). Grading cattle thus also takes place by techniques, where feeding, for example, emerges as a type of knowledge that is essential for "animal improvement ${ }^{38}$.

Such "care" allows us to enhance "persuasive fictions", in Strathern's (1999) terms, which can mobilize reflection. If, as I have thus far shows, we have, on the one hand, the construction of mestizo cattle that is at home in the forest and is bred according to "rudimentary" or "savage type" 39 techniques, known as "rustic" or

\footnotetext{
35 Briefly, the concept of the 'monument' refers to a Foucauldian archaeological posture in relation to discourse, when the researcher, in the role of an archaeologist of knowledge of discourse, searches in its subsoil - the unsaid, ignored and sacred - for the deep units that can deconstruct the so-called surface-effects.

36 For an example of the affinity between types of administrative knowledge and scientific discourse, see L'Estoille (2003). Inspired by the Weberian idea that the modern form of domination is characterized not only by force, but also by a belief in its legitimacy, the author identifies a continuity between administrative knowledge and the scientific discourse of research institutes created by the colonial State. The notion of "national domination" emerges here, with knowledge-specialists (scientists) supplying information, but also interpretative frameworks, for acting specialists (administrators), which contributes to the belief in the possibility of dominating a complex reality, making this domination legitimate in the eyes of those who wield it.

37 As Ribeiro (2008) claims, prior to the existence of a development project, local populations could hardly realize that their fate could be sequestered by an organized group of people from the technical elites.

38 According to Leal (2014: 124), breeders and zootechnicians tend to claim that "half of the breed goes in through the mouth".

39 This expression appeared in the zootechnic manuals until the middle of the $20^{\text {th }}$ Century (Leal 2014: 99) and relates to the type of management adopted in the colonial period, when animals were raised free, with the burning of pastureland. Valverde (1967: 247) notes that, during this period, breeders had to be watchful for herds to not go feral, and branding the with hot iron served not only to mark property, but also to tame them.
} 
"brutish" ${ }^{40}$, on the other hand we find "pure blood" animals which, as Leal (2014) describes, live in bays and "take regular baths and receive daily 'toiletries', have their pelt combed and cut, and their hooves treated". These receive a "royal treatment" ${ }^{41}$, linked to control over cutting-edge technology (balanced rations, vitamins, medicines, etc.), practices which, if I may infer, are required of the contemporary civilizing process (Elias 1994), where custom establishes relations of domination and hierarchy.

Indeed, in what pertains to the term "custom", I often heard the expression "cattle is custom", and that it is undergoing a process of transition: "I don't have the means anymore to transit with cattle (between natural pastures and rations). Today the cattle don't go to the forest, as it was with more common cattle. Holstein, Girolando, these are cattle that don't go into the forest. (...). Long ago you'd release a cow here and go get her close to grandfather's, and there wasn't this ration business". The speech brings out the agency of these animals ${ }^{42}$, but also their approximation to the sphere of custom - as they approach families and their habits - in a process that is fixed as both temporally and spatially linear, associated with the modernization of agriculture. As Otinho told me, "a cow, if she's raised on the trough and let loose in the field, she's spoilt".

"Making the cattle", by blood or custom, reveals that these are hybrid animals, biologically given but also constructed in the field of work and family relations. However, as we cross this threshold from "rudimentary" breeding toward a technological pattern, animals become "natural models", bearing a high genetic value, embodying characteristics of "advanced" societies, destined to be distributed (Escobar 1995) ${ }^{43}$. There is thus a type of purification - in the Latourian sense (1994) - that tends to promote the image of the "race" as a morphologically stable set of animals, resulting from a natural adaptation (Pellegrini e Marie-Dominique, 2014), which conceals the results of choices made, and creates a hierarchy between mestizo cattle raised "in the forest" (as local knowledge) and pure-blood cattle "raised on the trough" (through technology and hegemonic knowledge), although both these orders may be interchangeable in many farms. There is here a clear perspective in which the race (of animals) expressed the social, moral and economic position of (human and nonhuman) actors: inferior and superior; archaic and modern; primitive and civilized.

As Garcia-Parpet (2009: 40) claims ${ }^{44}$, when the condition of birth no longer matters as much for defining people, other refences are sought out (and found) to define elites and, consequently, the less favoured classes. The end of the colonial period (and slavery) in Brazil seems to have demanded redefinitions in the differentiated criteria of citizenship, involving biopolitical strategies of control over bodies and (human and nonhumans) practices, which were in accordance with the modernizing projects that, from the second half of the $19^{\text {th }}$ Century, sought to establish ways to include Brazil in the hall of so-called "civilized" peoples ${ }^{45}$. Such projects were permanently articulated with another, that disqualified historically subaltern peoples, where the imposition of racial classification on cattle (rather than directly on people), based on what they lacked or had in abundance, is a fundamental feature of the production of difference.

As is evident, the aspects that indicate a border can change, without thereby affecting that subsisting dichotomy (Barth 200o). The relation established with specific animals - control over racialized cattle, which involves not only blood, but also a range of forms of management - seems to subjectify an ethnic border insofar as it produces stratification by instilling a notion of productive inferiority in its animals and ways of

\footnotetext{
40 Term used for animals bred free in the fields, which are difficult to domesticate. Not by accident, it is also recurrently used to designate individuals with "no social tact", difficult to tame.

41 The term was taken from www.agrolink.com.br, a website dedicated to elite cattle.

42 In this context, it should be stressed that the cow is not a passive being, a mere recipient and reproducer of tasks, but an agent with a personality. In all farms which I went to, I heard words of respect and affection for the herd from farmers. "The cow is a very intelligent animal", which, for example, "knew the way" of transhumance, which can "hide the milk" during milking, "is choosy in it its feeding", and which, therefore, influences and conditions the management of the producers' different skills. I will return to this point later.

43 Or, in the opposite direction, they become synonymous with backwardness by being abolished through technical intervention.

44 The author studied the creation of elite food markets in France.

45 This term was later substituted by the expression "developed”. See Escobar (1995).
} 
life as naturalized truth. As Otinho's speech makes evident, owning such animals defines those from "around here" and those from elsewhere, a symbolic demarcation is established between an "us", possessing cattle that are not "special", and a "them", possessing a genetic "purity", with animals of "good race" - the small and the big, "those who work one way and those who work another way". As defined by Barth $(2000){ }^{46}$, ethnicity does not decode a catalogue of objective differences (territory, language, customs, common values, etc...), but may extend only to subtle features, so long as they are locally significant, over which they share orientation and general scales of evaluation.

We see here how the structuring of interactions within a wider society enables the persistence of cultural differences that define social identities, always relational and contrastive. After all, according to Barth (2000) ethnic distinctions do not depend on the absence of interaction and social recognition. On the contrary, they are generally the very basis upon which the social systems that convey these differences are built.

It is interesting to observe that these hierarchy-positions attached to the herd have also been established and created in various ways. In the case of cheesemaking, for example, those who use herds of the Gyr race in the state have, in recent years, come to "bear" the benefits of producing a milk with the special properties of the order of the sacred ("the nobility of the most ancient bovine race in the world, sacred in India and Brazil") or the medicinal ("Gyr cattle produce practically 100\% A2 milk, the protein of the milk does not cause intolerance or allergies"). A symbolic "distinction" - which gives these cattle and their producers access to elite cattle fairs ${ }^{47}$ - constructing groups with "differentiated" status, making use of the characteristic rewards of "purity" fixed to the animal so as to produce and stress qualitative characteristics:

"In 2006, we bought the bull Lenhador (Gyr) from Calçiolândia, which entered our herd to change our destiny. With its genetic force it made our still-backward matrix evolve in all necessary aspects for a modern cow that produces milk. We always selected focusing the Serro Cheese, the flavour of the cheese we produced was different, everyone who tried it liked it and said so... This cheese is different, why? I would the explain the rustic nature

of the Gyr that transmitted the flavour to the product and that's how the Gyr Cheese brand was born, to bring to a close some one hundred years of producing Artisanal Cheese in Serro region, with the nobility of the most ancient bovine race in the world, sacred in India and Brazil, the Gyr race" Túlio Madureira, farmer of the Serro (my emphasis) ${ }^{48}$

Although many farming families say that "mestizo" animals are adapted to the conditions that predominate in the region - claiming, for example, that "specialized" cows are more susceptible to health problems (such as mastitis ${ }^{49}$ or complications during birth), demand greater care and costs (because of the use of medications and rations based on maize and soy, as well as needing contracted specialists to care for them), are ill-adapted to the steepness of the Canastra, and possess fewer aptitudes than local cattle (which have historically produced milk, but also meat, leather, fat, grease, horns, as well as being used in traction and transport) - their animals are seen to be signs of technological backwardness, linked to lack of knowledge, and with a low commercial value. In brief, they are very distant from any ideal of purity and distinction.

\footnotetext{
46 Barth (2000) criticizes the "definition of the ideal type" of an ethnic group corresponding to each culture that was popular in the Functionalism of the time. For him, ethnic groups are, on the contrary, ascriptive native categories that regulate and organize social interaction within and outside the group, based on a series of contrasts between the "close" and the "distant".

47 In 2017, these cheesemakers obtained exhibition space at the ExpoZebu. Although they lack the financial capital of those who invest in or breed zebu beef cattle, they have other sorts of cultural capital which places them in a privileged position within the group, allowing them access to certain legalized elite markets. It is no accident that one of the chees producers that uses pure Gyr cattle has recently been invited to be president of the Artisanal Minas Cheese National Commission of the FAEMG, an agrobusiness agency that, as the site of the agency claims, "is an integral part of the Rural Patronage System, which is led by the CNA (Confederação da Agricultura e Pecuária do Brasil, Agriculture and Husbandry Confederation of Brazil)."

48 In: http://www.sertaobras.org.br/blog/2016/o1/29/gabriel-e-madureiras-encontro-de-criadores-de-gir-para-provar-o-queijo-mais-ecologico-do-brasil/

49 This is an inflammation of the udder, caused by germs that enter the milk duct and propagates throughout the herd.
} 
By seeking to "improve the blood" of their animals so that they obtain the characteristics of the Girolando, Otinho and Eliana once again toy with the incorporation of foreign techno-science that has increased the production of milk and cheese in the area - genetic improvement, but also nutritional and sanitary management - but which are absorbed into a contingent space of cultural intimacy, in which the affects and ethics of peasant exchanges carry weight, and transcend a standard of utility (Brandão 1999: 60). Along with an increased output, they also incur costs and risks by dependency on acquired technologies. They therefore proceed with care, running their calculations, fearing the loss of their productive autonomy, but also of altering their relations with other farmers and also with the animals. "Too much technology for us small farmers is not a good deal. If we put in a veterinarian, an agronomist, we go bust", claims Otinho. As I heard from another farmer: "I'm even afraid of getting updated. Because of the loans and the rising costs".

"Making the cattle" - which, in relational terms, means making oneself, since farmers make cattle and cattle make farmers - is a long process. If, on the one hand, it represent an archive, related to a social position, on the other hand it is also the place for work and managing the family, essential categories for the reproduction of a peasant way of life (K. Woortmann, 1988), which involves choices determined by relations that do not coincide with those recommended by technicians. As Woortman (1988: 17) notes, "it is not the past that survives into the present, but the past that, in the present, constructs possibilities for the future".

Although agricultural policies and current standards have tried to homogenize these practices, in what concerns local relations the model of "making the cattle" is not only tied to a market interest in the herd and its commercial value. It implies invention and creativity in the choice of animals as a function of their different attributes, not being limited to a simple repetitive execution within this hierarchy structure, since each farmer confers distinct sense and meaning to their practices.

Thus, many farmers throughout the region have singularly sought out different ways of "making the cattle", updating their husbandry model, based on choices that involve other forms of productivity, associated, for example, to qualitative aspects such as cutting costs and work time (due to the rustic nature of the cattle), better working conditions (due to the temperament of the animals), as well as factors of a moral order that imply other political and economic meanings.

"I think the good cattle are when each one has one colour, when it's not very standardized. When you have genetic variety, it may be that you don't have everything very good, but you won't have everything very bad either. If there's a problem, it won't affect the whole squad. The idea is to escape from this standardization. (...) As I see it, there are many ways to understand productivity. You may lose, in the sense that a Guernsey gives zo litres of milk, and then (mestizo cattle) will give you to litres, but you have other factors: quality, rustic nature, demands, etc." Luciano Carvalho, farmer, December 2016.

Another interesting case that I was able to follow in the state of Minas Gerais, are those farmers that gamble on "making the cattle" via the recuperation of selected traditional cultural traits, thus "pitching" the race of the animals on the history of the region in a process linked to the valuation of the Canastra Cheese as a product with a differentiated provenance ${ }^{50}$. "Inventing tradition", some farmers have sought, for example, to "return" to the Caracu herd. This is Zebu-like cattle has a low productivity when compared to other dairy breeds, but is tied to the knowledge of those who occupied the region and left it as their legacy. They thereby transmit the idea that this race is tied to a "more authentic" Canastra cheese.

50 Paxson (2013) observed a similar process among cheesemakers in the USA. 


\section{Making cattle and building families}

As with all dairy producers and cheesemakers in the region, Otinho and Eliana get up every day before six in the morning. There, as in the dozens of farms I visited in the last few years, some of the windows of the farmhouse are turned to the corral. Whenever I slept in one of them, I would wake up to the mooing of the cows "waiting" to be milked. The proximity of the house to the corral is symbolic of what the animals mean to the families. Along with the land, it is the most prized good in the region. It is not uncommon to find houses which share a wall with the corral.

To start milking, Otinho calls out each cow by its name: Ant, Plum, Smoke, etc. The names are uttered in a grave tone, always in an almost unintelligible Minas dialect (hard to understand even for those born in the state), in which names are shortened. Thus, for example, Boa Vista becomes “Bovista... Bovista...". He opens the doors and a cow strolls in the stall, without needing to make any great effort. In each of the troughs of the stall he puts two buckets with about $1.5 \mathrm{~kg}$ of ration. There are, however, variations among the animals. "It gives more milk, I give it more ration; it gives less milk, I give it less ration", claims Otinho, who also says that each cow has its own trough where it feeds during milking, and each member of the family milks their own cows daily.

What we see are varied ways of creating affinity and leaving the animals calm, leading the work to be carried out faster and more leisurely, respecting each cow's temperament. There are cows who "don't like" to be milked far from the herd, and there are also those who "hide their milk" when they are displeased. I heard from a local farmer that the individualization of each animal is what makes them differ from the industry, since for them each animal is unique, with its own personality, which the owner must come to know, while also understanding other elements that influence the animals, such as climate, vegetation, disease, and so forth.

Alongside a second lateral door, which divides the stall into two parts, Otinho calls the calf that slept "apart" from its mother, in the company of other calves. He uses the same abridged words: "Bovista... Bovista... Bovista...”. The calf, called by the same name as its mother, crosses the door, also already conditioned by the daily breakfast, and is tied next to its mother (another way of calming it down). Once more I hear: "cow is custom, they do what we make them used to doing".

When I ask Otinho why the calf has the same name as its mother, Otinho replies that the calf is called that way until it is weaned, after it which it becomes nameless for the period in which it stays in the pasture of the "bachelor cows". As I described earlier, this pasture is situated further from the corral and the farmhouse. If it is male, it will be sold after a few months, once it has gained weight, without ever having been named. It if its female, it will be baptized when it has its first progeny, and placed with the other lactating cows. "The calf is only baptized when it is an adult and will breed. Then it gets a name. Until it is weaned, it has the same name as its mother", Otinho tells me.

This situation means that it is the cow which is baptized with the birth of its first calf. These names are important since, as some farmers told me, it is through them that animal families are created, but it is also through names that proximity to them is established, and this is important in conducting daily activities. I assume that the absence of a name during this period of the calf's life is related to the distance of these animals, which for a period remain confined in the "pasture for bachelor cows" ${ }^{11}$ where the animals are, to use the terms I heard from a farmer, "less individualized", in the sense that they are not inserted into the daily universe of work and, consequently, are less tied to the families building their herds. 
In a study of cattle breeding in the French countryside, Deturche (2012) describes how the introduction of technical-scientific forms of breeding has been influencing the relations between breeder and herd, reverberating in the socio-political organization of the breeders. The author shows how the affective relations is detailed in a context where business management guidelines have ruptured the ties between breeders and animals, which lose their individuality. "De-individualized, cattle make up a compound bloc, placing the breeder, once again, in the neutral position of an administrator, since 'they are only cows, you can't mix everything'. Once more, by removing the affective side, the automatization of the herd follows" (Deturche 2012: 160)

This logic is perceived by the local farmers when they find their references challenged by modernization practices that have been gradually introduced into the region, as one of them made clear to me:

"Because with the breeding of beef cattle, the owner of the cattle doesn't know the cattle, it's all the same. [Our] cows all have a name. Every cow has a name, the calves learn the name of the cow. In my house, for example, we have a Brown, Browny, Black, Blacky. So, you call the cow and it comes. It is known by the name and it comes. And the calf comes too. And this is old as well. Just like in the time of my grandfather, great-grandfather" (farmer from São Jose do Bairro, October 2015).

In the Canastra, as we can see, the logic of proximity and individuation persists, with farmers organizing their activities according to the characteristics of each animal. The relationship established with them, as the report quoted above makes clear, emerges once again as a subtle definition of an identity boundary, differentiating local inhabitants through a historical and cultural process, in which the names of animals is of great importance.

When, for instance, animals which are considered to be 'good animals' die or are sold - typically because of their age - their names are recycled in younger generations. The names of outstanding animals thus become a sort of family surname. Families of cattle are mapped from these prestige animals, their descendants being recognized and distinguished from others ${ }^{52}$. Through them, memories of the best cows a farm ever had and their descendants are activated. In fact, these animals remain present even after their death. Through new generations, of course, but also through their skulls, hung in the corral, a custom found in all of the farms I visited, where these animals remain as a type of guardian to ward off evil spirits ${ }^{53}$.

Following Ingold (2015)54, we may say that race emerges as a generalizing "appellative" (a common noun) of the world of nature, proper to an industrial/colonial society that maintains interactions with a place, producing ethnic diversity within larger and more extensive social systems. This appellative is predominant in larger landholdings, with greater use of technology. In contrast, the names (proper nouns) singularize animals within a local universe of affects, conferring on them individuality, behavioural codes, memory and place in the world, introducing them as "almost human companions" (Ingold, 2015: 244-245).

\footnotetext{
52 Genealogies of cattle families, much like genealogies of human families, are dotted with preeminent characters. The existence of herd lineages is hardly new, and the elaboration of genealogical trees and the formation of herds by animals that one has bred is present in research among breeds in the Chamonix Valley (Barré 1997) and among the "races" of the Hérens cow (Preiswerk, 1995: 31-39).

53 In an article called The Sacrificial Role of Cattle among the Nuer, Evans-Pritchard (1953) reviews the work of a number of authors who also point to similar practices involving the role of the "spiritual guardian" of cattle in different localities.

54 In a study called "Naming as storytelling: speaking of animals among the Koyukon of Alaska", Tim Ingold (2015) contrasts certain ways of naming and classifying in Western societies with the logic of Koyukon names for their animals. According to Ingold, two ways of classifying predominate in the West: one which singularizes the referent, which is the "proper name" (or just "name") that is used exclusively for humans, except for certain pets; and another, generalizing, which is a "common noun" (or "appellative"), used for "wild animals", plants and other things. According to the author, this distinction harks back to the nature / culture divide, which postulates the separation of human society from the domain of nature, and situates humans as unique individuals in opposition to a generic "nature".
} 
The singularization of these animals by names and their approximation to the family universe merits further attention. In a context in which young men pass into adulthood through their work - in which initiation in daily chores is a fundamental moment - the cow, previously considered a calf, also achieves this passage through "work", which begins with its first progeny. This is when it starts to carry out its task in the farm, being moved to the "pasture for lactating cows", close to the family space. The animal here gets named and starts to be a part of the "subfamilies" of cattle that are mapped in the memory of the farmers 55 . The age of cows, but also their position in the herd, comes to be counted by the number of progenies it has had ${ }^{56}$.

It is also interesting to think of the seasonal transference of "bachelor cattle" to the "pasture of lactating cows". It is in this latter place that a cow ceases to be a calf and constitutes a family, and here we find an ambiguity, since there is an animal family - approximating the cow to the bull of the property and the calf that will be born - but also that of people ${ }^{57}$. The history of the human family merges with the history of animal families; to speak of one is always to refer to the other, and both are in constant movement. Due to their relation of proximity and affect, it is sometimes said that they "are part of the family".

In a study of the hinterlands of Pernambuco, Marques and Villela (2017) show how the category of the "family" is constituted through a "selection that depends upon various criteria". Rather than being given, it is something that one learns and produces. They show, for example, that the signage on the ears of goats and the cattle irons are a graphic expression of the ways of making family. In their field, the "processes of lineage and territorial segmentation, of ramification and junction, of mixture and purity of "blood", are partially coextensive and can be observed" (Marques and Villela, 2017: 40). Thus, if the family - in its distinct meanings and formats - is a notion tied to a pedagogy of daily life, I here opt for categories such as "work", "memory" and "affects" as central factors in the dynamics of the constant and circumstantial constitution and redefinition of what is considered family, with people, but also animals, mutually composing each other ${ }^{8}$.

This nearness might help to explain why cows are rarely slaughtered in the families of the region. In Matinha, for example, people eat pork, chicken and fish, all obtained from the farm, but meat is always bought in the market, a situation which is not uncommon in the region. "We don't feel right killing them. Old people say it's no good to eat cows from the land. And we also don't like to sell them. It's kind of a sacred animal to us", told me Otinho.

Some years ago, health norms prohibited the slaughter of cattle within farms. However, the contempt for eating cows from one's own farm in the region seems to precede this state-wide norm by quite some time. For example, in a report on his travels through the Valley of the São Francisco River in 1817, Auguste Saint'Hilaire indicates that this custom was already prevalent in the region:

\footnotetext{
55 Evans-Pritchard (1953) describes a moral identification between bulls and young Nuer boys, with the latter receiving the name of their favourite animal when they undergo the rite of initiation into manhood, both being brought into an intimate relationship that will last the rest of their lives. However, this new relationship with cattle does not only have a personal character, but also incorporates them into a wider lineage, with their symbolic use expressing the collective identification of clans and lineages with their herds.

56 Although the date of birth of each animal is marked into the cow's skin, a requirement of the health agencies for vaccination purposes, breeders calculate the age of the animal by the number of progenies rather than by how old they are.

57 The terms used to qualify the biological relations among animals are the same used for human kinship relations, such as mother, father, daughter, grandmother. There are some differences, however: the term "sister" is applied only to matrilateral relations, that is, to cows how have the same mother (Deturche, 2012).

58 A similar situation is described by Preiswerk (1995), in a study of the ties between humans and cows in the Valais region of southern Switzerland. He studies the construction of a vast type of empirical knowledge between peasants which, he argues, operates as a sort of bricolage, in which families of animals constitute the collective memory of the region, transmitted through generations. In this region, too, some animals are considered to be family members.
} 
"And if animals earn so little for their breeder, this is not due to the fact that, in this region, as in the south of Brazil, a part of the cattle is consumed in the meals of farming families, nor that they nourish themselves solely from the meat of their cows, since even wealthy people there only have beans, pork, milk, cheese and maize porridge at their tables" (Saint'Hilaire, 1937: 52.)

This relation recalls other ethnographic examples, such as the taboo on the "mother cow" among the Hindu, analysed by Marvin Harris (1978), who claims that the prohibition on consumption of the cow is a cultural response to an ecological adaptation, and the sacrificial rituals among the Nuer, described by Evans-Pritchard (1953). The latter author shows that, except on rare occasions of extreme necessity, the Nuer do not slaughter their cattle for meat, for slaughtering cattle outside ritual occasions is considered a grave trespass, which can harbour "ill luck"59. In general, both authors highlight that if they were to kill their animals for food, both peoples would actually reduce their food resources, as well as uses for fuel, religious purposes, etc.

Among local cheesemakers, cows are only sold in times of financial difficulty, when a debt needs to be paid, or when it becomes completely unproductive (old or in case of some physical defect), becoming costly for the farm. If, to an extent, this points to an economical relationality in which cattle act as a sort of savings and insurance for the family in times of need, which men need and which cannot be accessed in the same way with money (Ferguson, 1990), it also involves a series of non-commercial relations in which, as Brandão (1999: 6o) claims, one can discern the existence of affects and an ethnics of peasant exchange that cross the subtle tessitura of meanings and sensibilities, which are usually not noticed by (environment and health) agents, who periodically apprehend, and even slaughter, animals.

Despite being treated by men of science and public administration as a merchandise-artefact destined to be homogenized within biopolitical standards, cattle seem to participate in peasant lives as subjects, with which farmers establish daily affective interactions which involve a relation of identification and profound knowledge of the use of the environment, making these animals into more than mere economic goods. In this contingent of relationships, we find specific knowledge, accessed daily which, at present, challenges the asymmetry of foreign professional knowledge, anchored in legislation (Ribeiro 2008), but distant from the local universe.

\section{Concluding Thoughts}

Throughout this article, I have described the operation of a range of knowledges, temporalities and relations of mutual composition in a territory in the south of the Brazilian state of Minas Gerais, occupied by peasant families who have long been in conflict with constituted powers. The latter have sought to standardize local ways of life (for both humans and nonhumans) by different means, among which I draw attention to three: repressively (though different instances of the apparatus of inspection); morally (by adjudging the customs, animals and local instruments to be backward, and, therefore, replaceable); and economically (with incentives to adopt exogenous technologies, related to the loss of productive autonomy).

I have approached these three spheres by placing in the foreground complex ecological interactions with nonhuman forms of life that cross and co-constitute each other, making evident asymmetrical relations of power, forms of knowledge, interventionist policies, and modes of resistance. At the heart of the article we therefore find cattle, hybrid beings - effects of nature, but also the result of a mixture of a certain number of substances deriving from those who "make" them. From a dominant perspective, these have been constituted as "biological" artefacts ${ }^{60}$ (Leal, 2014), used for centuries by an expanding agricultural frontier (still expanding

59 According to Evans-Pritchard (1953), sacrifice among the Nuer is not merely a negative injunction. They do not sacrifice their bulls because they are considered "sacred", but, on the contrary, they are "sacred" only because they are set aside for sacrifice.

6o Taking Harraway as a reference, Leal (2014) refers to these animals in the hands of elites as artefacts of biological knowledge activated beyond scientific circuits. 
in Amazonia), for social distinction, and, as I have shown, in a type of colonization of knowledge, expressing - through research institutes, rural extension projects, and inspection - a common order in an evolutionist line that situates backward and advanced people and animals (constructing moral centres and peripheries of knowledge), converted into practices of social control.

It may seem that I have here dealt with yet another controversy between science and traditional knowledge. Yet, as Leal (2014) shows, the construction of elite cattle - as the construction of mestizo cattle in the Canastra - is an effect of a science of the concrete rather than of a science of laboratories or university departments. According to the author, while the attributes that objectify an elite animal may be buttressed by technology, they are also of the order of the sensible, with animals being evaluated in their totality by the intuition of selectors and breeders. The fundamental question is thus the retention of an important type of capital: proximity to the State (and its technocratic management mechanisms), with the great political efforts of elite producers to construct races that converge with their idea of the nation, and with these actors occupying different instances in national public administration ${ }^{61}$, being responsible releasing funds, approving legislation and norms that standardize knowledge, and putting these into practice, after which they can be recognized and ratified by technicians.

In contrast, I have shown how these animals build memories, knowledges and ways of life. In the Canastra they are constantly reinvented, within possibility, as a task of daily re-existence, despite local actors rarely being taken into account during decision-making processes. As one farmer said: "Maybe the participation of a farmer is too important for some people, but there is this residue of colonization which is still very strong. If there isn't a lab coat to evaluate it, then it's deferred". There remains an element of illegality, with the non-recognition and even challenges by the State (but also by private agents) of their practices and cultural references.

In what concerns environmental problems, for instance, this situation has currently generated in the Canastra hundreds of pending lawsuits involving farmers who countersue in expropriation claims and fines, demanding the recognition of their identity, their knowledge, and their right to remain in the properties as a traditional community ${ }^{62}$. In what concerns health norms, as mentioned previously, the vast majority of farmers survive in the informal market, with the food they produce travelling illegally, with traffickers, label falsifiers and detours from the main highways in the early hours of the morning to dodge inspection. All of this stems from mechanisms of political intervention, supported by networks of research and technical assistance, which imposes itself as the only possible and legitimate rationality.

Received: September 30, 2017

Approved: July 03, 2019

Translated by: Luiz Antonio Lino da Silva Costa

\footnotetext{
61 Leal (2014) uses the work of Palmeira (1989) to show that the State and rural businessmen are not exactly separate entities. More than an arbiter of the agricultural market, the State is the condition for the existence of rural businesses .

62 The case has become the largest conciliation process currently going through the Brazilian justice system, called 'Canastra: Justice and Reconciliation”: http://projetocanastra.com.br
} 


\section{Bibliography}

ANDRIOLLI, C.; PEREIRA, L. P. 2016. “Os dilemas da "criação": ambiguidades nos modos de se relacionar animais humanos e não-humanos em dois municípios mineiros”. Revista Teoria e Cultura, 11: 65-79.

BARBOSA, Cristiano. 2007. Território de Vida e Trabalho dos Pequenos Produtores de Queijo da Serra da Canastra: um estudo sobre a relação entre produção camponesa e espaços naturais protegidos nas nascentes do Rio São Francisco, Minas Gerais. Dissertação de Mestrado. UFU - Geografia.

BARRÉ, Silvestre. 1997. L'homme et les animaux domestiques aux Houches. Dissertação de Mestrado em Antropologia, Université ParisX-Nanterre.

BARTH, Fredrik. 2000. "Os grupos étnicos e suas fronteiras". In: O guru, o iniciador e outras variações antropológicas. Rio de Janeiro: Contra Capa. pp. 25-67.

BRANDÃO, C. R. 1981. Plantar, colher, comer: um estudo sobre o campesinato goiano. Rio de Janeiro: Edições Graal.

-1999. O afeto da terra: imaginários, sensibilidades e motivações de relacionamentos com a natureza e 0 meio ambiente entre agricultores e criadores sitiantes do Bairro dos Pretos, nas encostas paulistas da serra da Mantiqueira, em Joanópolis. Campinas: Editora da Unicamp.

BOUQUET, Mary. 1993. Reclaiming English Kinship. Manchester: Manchester University Press.

CANDIDO, A. Os parceiros do rio bonito: estudo sobre o caipira paulista e as transformações dos seus meios de vida. 6 ed. São Paulo: Livraria Duas Cidades, 1982. 284 p.

CARNEIRO, Ana. 2015. O povo parente dos Buracos: sistema de prosa e mexida de cozinha. 1. ed. Rio de Janeiro: E-papers.

CASSIDY, R. 2002. The Sport of Kings. Kinship, Class and Thoroughbred Breeding in Newmarket. Cambrigde: Cambridge University Press.

CINTRÃO, R. P.; DUPIN, L. V. 2018. "Queimadores de campo, fazedores de queijo e fiscais ambientais: controvérsias sobre o manejo do fogo na região do Parque Nacional da Serra da Canastra-Minas GeraisBrasil". Perpectivas Rurales. Nueva Época, $16(31): 5$.

DETURCHE, Jeremy. 2012. "As vacas da discórdia: Gestão e raça do rebanho entre os criadores de vacas montbéliardes na Haute-Savoie, França". Ilha, 14(1,2): 139-169.

DIAS, João Castanho. 2010. Uma longa e deliciosa viagem - O primeiro livro da história do queijo no Brasil. São Paulo: Edit. Barleus Ltda.

ELIAS, Norbert. 1994. O processo civilizador. Rio de Janeiro: Jorge Zahar Ed., vol 1.

ESCOBAR, Arturo. 1995. Encountering Development. The making and unmaking of the Third World. Princeton: Princeton University Press.

EVANS-PRITCHARD, E. 2013. Os Nuer. São Paulo: Ed. Perspectiva. . 1953. "The Sacrificial Role of Cattle among the Nuer". Africa:Journal of the International African Institute, 23(3): 181-198.

FERGUSON, James. 1990. The Anti-Politics Machine: "Development”, Depoliticization, and Bureaucratic Power in Lesotho. Cambridge and New York: Cambridge University Press.

FERNANDES, Vanessa Samora Ribeiro. 2012. Entre a regulação e a emancipação social: desafios à continuidade do lugar frente ao Parque Nacional da Serra da Canastra-MG. Dissertação de Mestrado. Belo Horizonte: Programa de Pós-Graduação em Sociologia - UFMG.

FOUCAULT, Michel. 1972. A Arqueologia do Saber. Rio de Janeiro: Forense Universitária.

GARCIA-PARPET, Marie-France. 2009. Le Marché de l'Excelence - Les grands crus à l'épreuve de la mondialisation. Paris: Éditions du Seuil.

HARAWAY, D. 2008. When species meet. Minneapolis: University of Minnesota Press. 
HARRIS, Marvin. 1978. “A Mãe Vaca”. In: Vacas, Porcos, Guerras e Bruxas: os enigmas da cultura. Rio de Janeiro: Civilização Brasileira. pp. 17-34.

INGOLD, Tim. Nomear como Contar Histórias: falando de animais entre os Koyukon do Alaska. In: Estar Vivo: ensaios sobre movimento, conhecimento e descrição. Petrópolis, RJ: Vozes, 2015.

LATOUR, Bruno. 1994. Jamais fomos modernos - Ensaios de antropologia simétrica. Rio de Janeiro: Ed. 34.

LEAL, N. S. 2014. Nome aos bois: Zebus e zebuzeiros em uma pecuária brasileira de elite. Tese (Doutorado em Antropologia Social) - FFLCH/USP, São Paulo.

LÉVI-STRAUSS, C. 1983. "Estruturalismo e ecologia”. In: O olhar distanciado. Lisboa: Edições 70. pp. 149-174. .1976. O pensamento selvagem. São Paulo: CEN.

L'ESTOILE, Benoit de. 2003. “Ciência do Homem e Dominação Racional”. In: B. L'Estoile, F. Neiburg, L. Sigaud (eds.), Antropologia, Impérios e Estados Nacionais. Rio de Janeiro: Relume-Dumara. pp. 61-93. LOURENÇO, Luís Augusto Bustamarte. 2005. A Oeste das Minas - Escravos, índios e homens livres numa fronteira oitocentista - Triângulo Mineiro (1750-1861). Uberlândia: UFU, pp. 353.

MARQUES, A. C.; VILLELA, J. M. 2017. "O sangue e a política: sobre a produção de família nas disputas eleitorais no sertão de Pernambuco". Revista Pós-Ciências Sociais, 14: 33-51.

MENESES, José Newton Coelho. 2006. Queijo artesanal de Minas - Patrimônio cultural do Brasil. Dossiê interpretativo - Vol 1. Belo Horizonte: IPHAN. 157 pp.

MORAES, M. D. C. 2009. Um povo do cerrado entre baixões e chapadas: modo de vida e crise ecológica de camponeses/as nos cerrados do sudoeste piauiense. In: Emília Pietrafesa de Godoi; Marilda Aparecida de Menezes; Rosa Acevedo Marin. (Org.). História Social do Campesinato Brasileiro. São Paulo: Editora da UNESP, v. II, p. 131-162

PALMEIRA, M. G. S. 1989. "Modernização, Estado e Questão Agrária”. Estudos Avançados, 3(7): 87-108. PAXSON, Heather. 2013. The life of cheese - Crafting food and value in America. Berkeley/ Los Angeles / London: University of California Press.

PELLEGRINI, Patricia; MARIE-DOMINIQUE, Ribereau-Gayon. 2014. “Qu'est-ce qu'une 'race animale pure'?”. Revue d'Ethnoécologie [en ligne], 5. Mis en ligne le zo juin 2014.

PINA-CABRAL, J.; GODOI, E. 2014. “Apresentação: Dossiê Vicinalidades e Casas Partíveis”. Revista de Antropologia, 57(2): 11-21.

PLOEG, Jan Douwe. 2008. Camponeses e impérios alimentares: lutas por autonomia e sustentabilidade na era da globalização. Porto Alegre: Ed. UFRGS.

PREISWERK, Yvonne. 1995. “Pour une ethnoculture de l'elevage vache set 'genealogies' dans la mémoire collective". Anthrol'ozoologica, 21: 30-39

RIBEIRO, Gustavo Lins. 2008. “Poder, redes e ideologia no campo do desenvolvimento”. Novos Estudos CEBRAP, 80: 109-125.

SAINT'HILAIRE, Auguste de. 1937. Viagem às nascentes do rio São Francisco. São Paulo: Companhia Editora Nacional.

STRATHERN, M. 1999. After Nature. English kinship in the late twentieth century. Cambridge: Cambridge University Press.

TSING, Anna. 2015. The Mushroom at the End of the World: On the possibility of Life in Capitalist Ruins. Princeton University Press.

VALVERDE, Orlando. 1967. “Geografia da Pecuária no Brasil”. FINISTERRA. Revista Portuguesa de Geografia, 2(4): 244- 261.

VAN DOOREN, Thom; KIRKSEY, Eben; MÜNSTER, Ursula. 2016. "Estudos multiespécies: cultivando artes de atentividade". Trad. Susana Oliveira Dias. ClimaCom [online], 3(7): 39-66. 
WOLF, E. R. 1976. Sociedades Camponesas. Rio de Janeiro: Zahar.

WOORTMANN, E. F. 1983. “O sítio camponês”. Anuário Antropológico, 81: 164-203.

WOORTMANN, Klaas. 1988. “'Com parente não se neguceia’: o campesinato como ordem moral”. Anuário Antropológico, 87: 11-73.

\section{Documento}

IBDF. 1981. Plano de Manejo do Parque Nacional da Serra da Canastra. Brasília: Ministério do Meio Ambiente.

Leonardo Vilaça Dupin

Institute of Philosophy and Human Sciences, Doctoral Program in Social Sciences,

University of Campinas - UNICAMP, Campinas/SP, Brazil

https://orcid.org/0000-0001-9013-187X

Author's email: leodupin@hotmail.com 